\title{
CONTESTING CALIPHATE \\ Opposition of Indonesian Fundamentalist Groups to ISIS Caliphate
}

\author{
Sahid HM \\ UIN Sunan Ampel, Surabaya - Indonesia | sahidhm@yahoo.co.id
}

\begin{abstract}
ISIS (Islamic State of Iraq and Syria) which was declared by al-Baghdādī as an Islamic caliphate (dawlah khilāfah) is not necessarily welcomed by Muslim fundamentalists in Indonesia. Hizbut Tahrir Indonesia (HTI) and Majelis Mujahidin Indonesia (MMI), two Muslims fundamentalist organization that struggle for Islamic caliphate, considers ISIS as deviant and invalid. This article aims to discuss the argument surrounding religious foundation of Islamic caliphate as believed al-Baghdādī as ISIS mastermind and the response of Indonesian fundamentalists to it. While all Islamic fundamentalism believes that establishment of Islamic caliphate is a religious obligation, they do not agree how to implement this obligation. ISIS's alBaghdādi is on the opinion that Islamic caliphate is to be implemented with all costs, including using violence and military campaign, Indonesian fundamentalists tend to use non-violence and dialogue as their strategy instead.
\end{abstract}

Keywords: Caliphate, Indonesian fundamentalist groups, Islamic State of Iraq and Syria, ISIS.

\section{Introduction}

The emergence of Sunnite Islamic fundamentalist group of ISIS (Islamic State of Iraq and Syria) under leadership of al-Baghdādī has stunned the world, including the Muslims. They wage the armed resistance against Iraq and Syria that happen to be controlled by Shiite regimes. This sudden and fierce military campaign of ISIS has made the two regimes incapable of containing their advance. Piece by piece, the territory of Iraq and Syria were captured by ISIS. In this territory, al-Baghdādī declared the emergence of al-Dawlah al-Islamiȳah fì 'Irāq wa 
al-Sham (The Islamic State of Iraq and Syria). ${ }^{1}$ As the event unfolded, it turned out that ISIS intends to expand its territory. This means further threat to Iraq and Syria, the two states suffered from internal political and sectarian turmoil, as well as the rest states in the region.

The ISIS phenomenon then spread to Muslim-populated states in other regions, thanks to internet and other media. In Indonesia, since August of 2014, the government was made busy in dealing with jihad movement that claimed to be affiliated to ISIS. ${ }^{2}$ In Pasuruan of East Java, one person named Salim Mubarok al-Tamimi al-Indonesiy claimed to be an army chief of ISIS. Furthermore, an Indonesian citizen named Wildan Mukhallad was reported to have died in suicide bombing attempt in Iraq. National agency for contra terrorism stated that there are 56 Indonesian citizens joining the armed ISIS. ${ }^{3}$

This development arouses various reactions and comments from the governmet and Muslim groups in Indonesia. The ministry of Law and Human Rights denounced the spread of ISIS understanding of Islam in Indonesia ${ }^{4}$ and quickly banned the ISIS in Indonesia since it has understood Islam as totality and struggled for Islam with any available means including violence and crimes. It wages war not only to the rest of Muslims who they think to have deviated from their understanding of pristine Islam but also to the West who in many cases they consider to have causes bad fate on Muslims worldwide. ${ }^{5}$ In addition to that, the government also banned ISIS because it has

1 See http://id.wikipedia.org/wiki/Negara_Islam_Irak_dan_Syam, accessed on 28 November 2014.

2 Kompas, "Dilarang Penyebaran Paham ISIS", 5 August 2014.

3 Ansyad Mbai (Head of National Bureau against Terror) states that until 2014 there are concentration of terrorist network spread across Indonesia. See Reno Muhammad, ISIS: Kebiadaban Konspirasi Global (Jakarta: Noura Books, 2014), p. 63. Compare it with Abd. A'la, "Terorisme dan Globalisasi," in Jabiliyah Kontemporer dan Hegemoni Nalar Kekerasan: Merajut Islam Indonesia Membangun Peradaban Dunia (Yogyakarta: LKiS, 2014), p. 7.

${ }^{4}$ Kompas, "Dilarang", 5 August 2014.

5 The decision of the government to combat fundamentalist radicals has not been perceived as combatting Muslims, instead it is a combat against terrorists. See Bernard Lewis, The Crisis of Islam: (Islam dalam Krisis: Antara Perang Suci dan Teror Kotor), translated by Muhammad Harir Muzakki (Surabaya: Jawa Pos Press, 2004), p. 1. Read Z.A. Maulani, "Di Balik Isu Terorisme", in Z.A. Maulani et.al, Islam dan Terorisme: Dari Minyak Hingga Hegemoni Amerika (Yogyakarta: Ucy Press, 2005), pp. 68-69. 
applied a version of Islamic law, especially criminal law, which is not suitable to aspiration of majority Muslims in Indonesia.

On the other hand, however, Indonesia is not sterile from Islamic fundamentalism phenomenon. Among Islamic fundamentalism group in Indonesia are Hizbut Tahrir Indonesia (HTI) and Majelis Mujahidin Indonesia (MMI). For them, ${ }^{6}$ ISIS should theologically be responded because ISIS has claimed that its goal is to establish and Islamic caliphate which is also the ultimate goal of HTI. ${ }^{7}$ That immediate answer is that the Islamic caliphate that ISIS is now campaigning is substantially contradictory to sharia. Therefore, HTI refuses to acknowledge ISIS as an organization that struggle for the establishment of Islamic caliphate. ${ }^{8}$

The position of HTI is considered odd because HTI believe that the establishment of caliphate is arguably more crucial and ultimate than observance of Islamic dogma. For HTI activists, caliphate is the ultimate goal. ${ }^{9}$ This is apparent in every HTI handbooks, indoctrination sessions and seminars. HTI Bulletin also always talks about khiläfah Islämiyah (Islamic caliphate). In all mass rallies arranged by HTI, regardless the issue, caliphate is the one and only solution.

In addition to HTI, Majelis Mujahidin Indonesia (MMI) that struggle for Islamic state also considers ISIS's Islamic caliphate as heretical. ${ }^{10} \mathrm{MMI}$ argues that to implement sharia, which is the ultimate God's command, the establishment of an Islamic state is a prerequisite. Since the idea of implementing sharia of the main goal of MMI, its opposition to ISIS's caliphate is difficult to understand.

\footnotetext{
${ }^{6}$ Those two groups are labeled as extreme right by the government. Tholhatul Choir and Ahwan Fanani (ed.), Islam dalam Berbagai Pembacaan Kontemporer (Yogyakarta: Pustaka Pelajar, 2009), p. 431.

7 According to HTI leadership such as al-Nabhānī and Zallūm, the period between Prophet Muhammad SAW in Medina and the demise of ottoman Dinasty in March 1924 is Islamic caliphate period. See Taqiy al-Dīn al-Nabhānī, al-Dawlah al-Islämìyah (Beirut: Dār al-'Āmmah, 1994), p. 224. Read 'Abd al-Qadīm Zallūm, Niżām al-Hukm fi al-Islām (Beirut: Dār al-‘̄̄mmah, 1992), p. 87.

8 http://www.muslimedianews.com/2014/08/tanggapan-gerakan-gerakan-islam-terhadap.html, accessed on 18 November 2014.

9 Ainur Rofiq al-Amin, Membongkar Proyek Kbilafab Ala Hizbut Tabrir di Indonesia (Yogyakarta: LKiS, 2012), p. 40.

10 http://nasional.news.viva.co.id/news/read/529558-dua-unsur-sesat-isis-menurutmajelis-mujahidin-indonesia, accessed on 18 November 2014.
} 
This phenomenon shows that caliphate contains conceptual and applied problem. This debatable concept of caliphate intensified when ISIS caliphate was declared and Indonesian Muslim fundamentalist groups oppose it.

\section{Historical Glance of ISIS Movement}

The emergence of ISIS was triggered by the aggression of the United States to Iraq that ended with the fall of Saddam Hussein regime in. This event created hatred of many Arab Muslims toward the US. On the other hand, this already hateful condition provided fertile ground for al-Qaeda network to recruit new followers in Iraq. ${ }^{11}$ Some analysts speculated that al-Baghdādī's ISIS was one of these al-Qaeda's newly formed cells. ${ }^{12}$ Hence, after the destruction of al-Qaeda as a consolidated group in Afghanistan, many dismissed al-Qaeda. Some small active cells that launched terror attacks here and there in the conflict areas might had similar patterns to al-Qaeda, but not officially affiliated to it. ${ }^{13}$

In the violence-invested area of Northern Iraq, the population is Sunnite Muslims and Saddam Hussein's loyalists. Their resistance towards the central government is understood as an agenda to return the power to the Sunnite Saddam Hussein's loyalists. This is because the reigning regime is Shiite, and the Iraq President, Nūrì al-Mālikī is a Shiite. Thus, another dimension of the civil war in Iraq and Syria is the repetition of sectarian conflict in Middle East between Sunnite and Shiite as it had happened in 2006-2007 which claimed thousands of lives. ${ }^{14}$

The violence in the 2000s still lingers in Arab minds, be they Sunnite or Shiite across the Middle East. For Sunnite, this not so long

${ }_{11}$ As'ad Said Ali, Al-Qaeda: Tinjanan Sosial-Politik, Ideologi dan Sepak. Terjangnya (Jakarta: LP3ES, 2014), p. 328.

12 http://id.wikipedia.org/wiki/Negara_Islam_Irak_dan_Syam, accessed on 28 November 2014.

13 The emergence of al-Tawhìd wa al-jibäd group in Iraq under leadership of Abū Mus'ab Al-Zarqāwī is thought to have similarity with al-Qaeda although put itself under al-Qaeda. See Greg Fealy and Anthony Bubalo, Jejak Kafilab: Pengarub Radikalisme Timur Tengah di Indonesia, translated by Akh. Muzakki (Bandung: Mizan, 2007), pp. 7676. Before that, this group is based in Herat, West Afghanistan. Since it considered necessary to operate in Iraq, al-Zarqāwī moved to North Iraq. Ali, Al-Qaeda, p. 328.

14 Aula, "Telah Lahir Negara Khilafah," in Majalab Nabdlatul Ulama, ed. XXXVI (August 2014), p. 45. 
past failure and current subordination under two Shiite rulers in Iraq and Syria might inspire the emergence of another jihadi group who try to overturn the history. Thus, islamist groups such as Jamä at al-Tawhid wa al-Jihäd under leadership of al-Zarqāwi seized the momentum to launch his jihad campaign. ${ }^{15}$

Although the US successfully assassinated al-Zarqāwī group who were actively engage in jihad campaigns since 2005, the resistance from militant groups continued in Iraq. After al-Zarqāwì’s assassination, Abū Ayyūb al-Masrī resumed the resistance. He, in October 2006, declared the establishment of Dawlah Islamiyah fi Iräq or Islamic State of Iraq (ISI). In 2007, the 2.250 volunteers from Northern Syria and Chechnya under leadership of Abū 'Umar al-Shishanī joined ISI. ${ }^{16}$ This bolstered the strength of ISI to tremendous extent.

Meanwhile, on April 19'th 2007, Abū 'Umar declared the establishment of Dawlah Islamiyah fi Iräq or Islamic State of Iraq (ISI). This was followed by the announcement of cabinet members consisting of 10 persons. Abū 'Umar was deputy chief in al-Qaeda, who in this establishment became the chief commander of ISI. In April 2010, both Abū Ayyūb al-Mastī and Abū 'Umar were killed near Tikrit, Iraq. After their death, the ISI leadership was resumed by Abū Bakr al-Baghdādī who was sworn to assume the position since May $15^{\text {th }}, 2010 . .^{17}$

In addition to rebel movement led by al-Baghdādī in Iraq, in last decade Sunnite ulama in Iraq is also active in arranging peaceful actions demanding equal rights by forming Sunni Ulama Front. The Iraqi government did not listen to their demands which create voices within the Front to support ISI. Although at the end the Front did not officially support ISI, it is publicly known that the Front justified ISI's campaigns simply because it was the only resistance that could bring solution in dealing with the fanatic Shiites. ${ }^{18}$

From the events that unfolded after the fall of Saddam Hussein, many Muslims in the region believe that the US is the most responsible one for the cycles of violence. The US has planted time bomb in Iraq,

\footnotetext{
15 Ali, Al-Qaeda, p. 328.

16 Ibid., p. 330.

17 Ibid.

18 http://www.eramuslim.com/suara-kita/suara-pembaca/menggempur-isis.htm\#.VGk43FfXvIU, accessed on 28 November 2014.
} 
they say. In the neighboring country of Syria that is ruled by another Shiite, the Sunnite uprising began. Sunnite militants rooted in $\mathrm{Hizb}$ alTahrir joined with those Sunnite not satisfying with al-Mālikī. However, not all Sunnite groups supported the ISIS declaration, because their initial goal is merely criticizing non-accommodation policy adopted by al-Mālikī. ${ }^{19}$ Al-Baghdādī's ISIS is more appealing than al-Qaeda. They valued al-Baghdādī as a brilliant military tactician. ${ }^{20} \mathrm{Al}-\mathrm{B}$ aghdādì's personal prowess then unchallenged after his success in expanding the territory of Islamic State of Iraq (ISI) and renamed it as Islamic State of Iraq and Levant (ISIL). ${ }^{21}$ On the other hand, ISIS jihadi groups originating from Syria have returned to Syria and formed Jabhat al-Nus rab with the mission of opposing Bashar Assad. ${ }^{22}$

It is on that context that ISIS emerged. ISIS is a logical consequence of socio-political instability in the Middle East. Jihad campaigns that were deployed were continuation of the ultimate goal of Muslim revivalists-fundamentalists in establishing dawlah Islamiyah (Islamic state). ISIS now gradually becomes new emerging force that ready to pose resistance on ruling powers in the Middle East that they consider incapable of realizing the mission to establish an Islamic state and implement sharia comprehensively. Given this goal has been shared by many Muslims worldwide, the support for ISIS or at least their ultimate goal will, and already spread to Muslim populated countries beyond the Middle East, including Indonesia.

\section{Caliphate as the Ideological Basis of ISIS}

The caliphate that ISIS establishes represents a fundamental ideology, ${ }^{23}$ an ideology that is based on the doctrine that is built upon the assumption of pure early period of Islam. Admittedly, this doctrine is not new in Islamic political history. The spirit of reform of this movement seeks for purity of Islam and idealizes an Islamic political

\footnotetext{
${ }^{19}$ Aula, "Telah Lahir," p. 45.
}

20 http://www.tempo.co/read/news/2014/07/01/118589519/Misi-Berbelok-ISISTak-Akur-dengan-Al-Qaidah, accessed on 29 November 2014.

${ }^{21}$ Levant is other name for Syam which is composed of Syria, Lebanon and Palestine. This declaration consists of statement that Jabhat al-Nus rah (JN) is a part of ISIS/ISIL. See Ali, Al-Qaeda, p. 330.

22 Ibid., pp. 338-339.

23 Read Bagus Takwin, Akar-Akar Ideologi: Pengantar Kajian Konsep Ideologi dari Plato Hingga Bourdien (Yogyakarta: Jalasutra, 2008), pp. 36-38. 
entity for Muslims based on the political practices of the Prophet Muhammad. In al-Baghdādī's point of view, ISIS is the manifestation of ideal Islamic political entity that is directed to work on reforming Muslims' thought and implementing sharia founded upon pristine Islamic doctrine. It is the anti-thesis of West-sponsored democracy. Like other religious movements that blame on outsider for own misfortune, al-Baghdādī believes that Muslims' current poor condition is as a result of colonialism and global capitalism. For that reason, their resistance is aimed at neo-liberalism and capitalism of the US. As it has been campaigned by Osama bin Laden, this is laid upon the assumption rest on early Islamic political practices. ${ }^{24}$ ISIS militia rebelled against al-Mālikī in Iraq dan Assad in Syria because they believe that the two regimes are collaborators of the West and therefore must be rejected at all cost. ${ }^{25}$

This world view actually is rooted in Islamic modern thought that has the goal to the glory of early Islam by rejecting innovation in religion which is alredy corrupted from its original spirit. They denounced the last Islamic Caliphate of Ottoman because it had deviated from their version of pure Islam. Thus, they intend to create own caliphate. ${ }^{26}$

This reform of Muslim thought is an effort to deal with the backwardness and poverty of muslim world as well as to provide roadmap for Muslims to return to pristine teaching of Islam. This movement had been flourished in the second part of IX century CE. The main mastermind was Jamāl al-Dīn al-Afghānī, Muḥammad 'Abduh, and Rashīd Rị̣ā. Later, Hasan al-Bannā' and Sayyid Quṭb were highly responsible for al-Ikhwān al-Muslimūn's ideology. The thought the last two personalities were dyed with anti-West sentiment. ${ }^{27}$

Ideology speaking, ISIS phenomenon has similarities with alIkhwān al-Muslimūn that deeply involved in the political turmoil in

\footnotetext{
24 Ali, Al-Qaeda, pp. 16-17.

25 http://id.wikipedia.org/wiki/Negara_Islam_Irak_dan_Syam, accessed on 28 November 2014.

26 Ibid.

${ }^{27}$ Ḥasan al-Bannā’ (1906-1949 M) was a charismatic and influential Egyptian Muslim who found al-Ikhwān al-Muslimūn 1928 di Ismailiyah, southeastof Cairo, Egypt. His movement spread in Muslim world. See Anouar Abdel-Malek (ed.), Contemporary Arab Political Thought (Bath: The Pitman Press, 1980), p. 45.
} 
Egypt since the latter opposed the British occupation and the creation of Israel on Palestinians' land. ${ }^{28}$ Al-Ikhwān al-Muslimūn believed that the political establishment that founded upon Arab nationalism had failed, because it blatantly imitated European countries which had separated religion and politics. For al-Ikhwān al-Muslimūn, the West did not provide enough space for Christianity to regulate profane affairs, whereas in al-Ikhwān al-Muslimūn's mind, the ideology of Islam could not be realized if not applied as the rule for all aspects of life. It meant creating regulation based on Islam for all human affairs. ${ }^{29}$

In the discipline of figh siyasab (Islamic political science), the thought of al-Ikhwān al-Muslimūn is frequently referred as the pattern for contemporary Islamic fundamentalism movement in Muslim world, ${ }^{30}$ including ISIS. As other fundamentalism movement, alBaghdādî̀s followers intend to establish Islamic state and apply sharia for that state. To achieve this goal, they refuse to make dialogue and other peaceful means, except with those who agreed with their goals and swear to be loyal with ISIS caliphate with bay'ah. As a result, their only means is violence and terror which they call jihad. ${ }^{31}$

Under the banner of jihad, this militias under the command of alBaghdādī marched force fully to fight the Iraqi and Syrian regimes whom they consider not applying sharia. After those militias captured some areas from Iraq and Syria, they declared ISIS and appied strict sharia, notably Islamic criminal law along with its hand amputation for thieves, stoning for adulterers, and crucifying those who not performed Ramadan fasting. ${ }^{32}$ They consider their approach as the only true in applying Islam. Other Muslims who do not agree and

\footnotetext{
28 In the 1940s, al-Ikhwān al-Muslimūn aunched series of violent attacks targeting the government facilities. As a result, King Farooq of Egypt banned its activities in 1948. Al-Ikhwān Muslimūn's goal was to establish Islamic state in Egypt. See Munawir Sjadzali, Islam dan Tata Negara: Ajaran, Sejarah dan Pemikiran (Jakarta: UI-Press, 1993), p. 145.

${ }^{29}$ M. Imdadun Rahmat, Arus Baru Islam Radikal: Transmisi Revivalisme Islam Timur Tengah ke Indonesia (Jakarta: Erlangga, 2007), p. 46.

30 Azyumardi Azra, Pergerakan Politik Islam: Dari Fundamentalisme, Modernisme Hingga PostModernisme (Jakarta: Paramadina, 1996), p. 115.

${ }^{31}$ Read Zulfi Mubaraq, Tafsir Jihad:Menyingkeap Tabir Fenomena Terorisme Global (Malang: UIN-Maliki Press, 2011), p. 90.

32 Read Reno Muhammad, ISIS: Kebiadaban Konspirasi Global (Jakarta: Noura Books, 2014), p. 48.
} 
oppose ISIS are considered infidels and apostates. ${ }^{33}$ ISIS caliphate stresses that after it has been declared, the only obligation for Muslims is to swear the loyalty and obey. ${ }^{34}$

ISIS believe that only rightful authority can wage and lead jihad and the first thing of jihad is waging war against non-Muslim states to purify Islam. Other muslim resistance groups are considered unauthorized representation of Islam. For ISIS, HAMAS of Palestine are apostate and have no right in waging war against Israel. ${ }^{35}$ Too, ISIS attacked Shiite sects, Yazidi minorities, Kurds, and certainly nonMuslim in the nearby areas. Those other Muslim groups are forced to pay obedience to ISIS, whereas non-Muslims are given the choice of converting to Islam, paying tax, or leaving the territory occupied by ISIS and give all properties to ISIS. 36

Simplistically speaking, ISIS is a true manifestation of caliphate that represents a political ideology that concerns with Islamic fundamentalism agenda. However, it can not be considered as political institution. At least, ISIS phenomenon reflects caliphate institution that had been dreamed by those extreme fundamentalists. ISIS constructs the Islamic political heritage into reality. As an Islamic caliphate, they also use jihad to justify violence, killing and war to implement sharia. Predictably, ISIS's caliphate is not warmly welcomed by the rest Islamic fundamentalist groups for some reasons. Initially, those groups speak about normative aspects about caliphate, but at the end, it is obvious that the talk is about political contestation with various interests and goals. ${ }^{37}$

33 http://id.wikipedia.org/wiki/Negara_Islam_Irak_dan_Syam, accessed on 28 November 2014. Al-Baghdādī claimed that Muslim youths have the aspiration to establish Islamic state in form of caliphate since they consider caliphate the ideal form of Islamic state.

34 http://heniputra.my.id/isis-jatuh-ke-dalam-perangkap-deklarasi-khilafah-yang-tidakakan-merubahnya-dari-sebuah-kelompok, accessed on 28 November 2014.

35 http://id.wikipedia.org/wiki/Negara_Islam_Irak_dan_Syam, accessed on 28 November 2014.

36 Muhammad, ISIS, pp. 49-53.

${ }^{37}$ When ISIS declared its caliphate, it recited the Quran (24:55 and 61:4) which contain the promise of God Almighty for the believers and those who do good deeds. The Quran (61:4) is verse contain the injunction to do jihad. HTI justify the obligation of establishing caliphate on the Holy Quran (5:48-49) which oblige Muslims to use God's law to regulate life. This verse necessitates God's law guardian, who in HTI understanding is a caliph. Fundamentalist Muslims also often cite several verses of the 
From the perspective of Islamic political science, there are some theoretical frameworks concerning caliphate. Among the earliest is Ibn Taymiyah who expresses his reservation about caliphate even though there are several textual references in the Holy Quran. This reference concerns the concept of governance, authority, and umma. ${ }^{38}$ Still, Ibn Taymiyah does not deny the importance of government, but he relates it with the conception of human as political being shaped by history. ${ }^{39}$ Thus, from the perspective of Islamic political sciences, governance in this sense is more historical and the product of tradition, not textual reference as believed by ISIS.

Based on this point of view, caliphate is a concept that emerges from Islamic political tradition. Thoha Hamim also acknowledged this point. He argues that caliphate concept is not laid upon strong and conclusive textual foundation. There is no template of caliphate system that can be applied universally across time and space (one size fits for all). The Holy Quran and prophet tradition do not determine system and form of caliphate institution, let alone the organizational structure and philosophical underpinnings. Since the period of the Prophet Muhammad, Muslim community had been living under political entity with various naming and features. ${ }^{40}$ Thus, caliphate is a historical property, not sharia.

Some Muslim intellectuals try to prove that the first and second Bay'at al-Aqabah, the agreement between the Prophet with the Madinah's representative of 'Aws and Khazraj clans, was the first cornerstone of Islamic polity. ${ }^{41}$ Yet, the Islamic polity is oriented in the

Holy Quran (4:58, 59, and 65), (5: 103), and (23:51). In addition, there are also several verses they cite. Medieval Muslim scholars Ibn Abī Rabī' Ulama cited (6:165) and (4: 59), Ibn Taymiyah cited (4: 58-59). However, those verses do not specifically speak about caliphate and political establishment.

38 Ibn Taymīyah, Minhäj al-Sunnah (Beirut: Dār al-Kutub, n.d.), pp. 2-3.

39 Khalid Ibrahim Jindan, Teori Politik Islam: Telaab Kritis Ibnu Taimiyah Tentang Pemerintaban Islam (Surabaya: Risalah Gusti, 1999), pp. 40-41.

40 Thoha Hamim, Islam dan NU di Bawah Tekanan Problematika Kontemporer: Dialektika Kebidupan Politik, Agama, Pendidikan dan Sosial Masyarakat Muslim (Surabaya: Diantama, 2004), p. 7.

41 According to Rais, the two Bay'at al-'Aqabab were similar to social contract that was conceptualized by some modern political philosophers and considered as foundation for the establishment of nation state and government. See M. Dhiauddin Rais, Teori Politik. Islam, translated by Abdul Hayyie al-Kattani (Jakarta: Gema Insani Press, 2001), p. 7. 
chiefdom of Madinah, not kbiläfah. Bay'at al''Aqabah, this agreement is considered an important feature in Islamic political sciences. ${ }^{42}$

This classic evidence shows that caliphate in Islamic political sciences do not have normative reference, since it evolved ${ }^{43}$ and manifested in various forms and concept. Forms and criteria of caliphate, indeed, emerge from history. Based on this understanding, it can be understood that caliphate is social institution that functions as a changeable institution following social change across time and space. By analyzing caliphate history, establishing caliphate that is not deeply rooted in current reality is contradictory to the very feature of caliphate as social institution.

\section{HTI and MMI, The Islamic Fundamentalist Movement in Indonesia}

Many observers categorize Hizbut Tahrir Indonesia (HTI) and Majelis Mujahidin Indonesia (MMI) as Muslim fundamentalist groups. This is understandable since according to William Montgomery Watt religious fundamentalism is an English term to signify Protestants who believe that the Bible should be accepted and interpreted literally.44 Thus, in the context of Islamic movement, groups who accept the message of the Holy Quran literally, although only for some select verses, might be related to the term of considered fundamentalists. HTI and MMI has aired the discourse of and campaigned for the implementation state-level of sharia comprehensively. So, the two groups can be considered of having literalistic interpretation and bear the name of fundamentalism.

HTI predictable is affiliated to Hizb al-Tahrir established in 1953 by Taqiy al-Nabhānī (1909-1979) in al-Quds Palestina. ${ }^{45}$ The activities of

42 Muḥammad Yūsuf Mūsā, Nizām al-Hukm fì al-Islām (al-Qāhirah: Dār al-Kitāb al'Arabī, 1963), p. 20. See 'Abd al-Qādir Zaydan, al-Fard wa al-Dawlah fì al-Sharìah alIslämìyah (al-Ijtihād al-Islāmi al-'Alamī, 1970), p. 13.

43 This change affirms the opinion that caliphate is an ever-changing institution since it is a social institution. This can be viewed from different attributes of the caliphs, namely khalifat al-Rasül, amir al-mu'minin, sultän, shah, prime minister, president in in different time and space. These attributes do not mean subordinate to caliph, instead, they have connotative meaning of symbolic authority. Bernard Lewis, Political Language of Islam (Chicago: University of Chicago Press, 1988), p. 51.

44 William Montgomery Watt, Fundamentalisme Islam dan Modernitas, translated by Taufik Adnan Amal (Jakarta: RajaGrafindo, 2001), pp. 3-4.

45 al-Amin, Membongkar, p. 21. 
this HTI is Islamic politics and ideology. HTI officially declared its existence in Indonesia by holding an international conference in national stadium of Senayan. ${ }^{46}$ HTI utilizes internet in campaigning its Islamic ideology in Indonesia and in communicating with its head quarter in Jordan. This last point serves HTI as a method for updating information, thought, ideas and latest ideological discourse in Hiz̨ alTahrir worldwide, but especially of the Middle East. ${ }^{47}$

The discourse that HTI builds is that Muslim life in Indonesia is not Islamic because the political and legal frameworks are not Islamic. Indonesian legal system is based on Dutch legal system on which HTI considers secular and therefore not Islamic. This not Islamic system has contributed to poor condition of social condition in Indonesia. So many breaches of law are not punished. ${ }^{48}$ To HTI, this signifies the incapability of the current not Islamic legal system. The only cure is by replacing the current legal system with Islamic legal system. ${ }^{49}$

HTI only acknowledges the only authority of God's law and fights for its comprehensive implementation to include both private and public aspects of law. This is as a sign of Muslims' total obedience to Islam. To realize this ideal legal system, HTI proposes Islamic caliphate. Thus, HTI calls for the return to the pure teaching of Islam. ${ }^{50}$

Apart from HTI, there is Majelis Mujahidin Indonesia (MMI). MMI is an Indonesian Islamic movement organization that is actively campaigning for the implementation of sharia within the existing political arrangement. MMI was declared on $7^{\text {th }}$ of August 2000 in a conference called mujahidin congress. This conference was held to respond unfavorable policies of the Old Order and New Order regimes that had curtailed Muslims' interest in Indonesia. for MMI, Muslims in Indonesia are in the state of back wardness since the independence of Indonesia in 1945. The only solution of this back wardness is the implementation of their version of sharia. ${ }^{51}$ Sharia, in

\footnotetext{
46 Afdlal et.al, Islam dan Radikalisme di Indonesia (Jakarta: LIPI Press, 2005), pp. 265-266.

${ }^{47}$ Rahmat, Arus, p. 78.

48 Afdlal et.al, Islam, p. 269.

${ }^{49}$ Ibid.

50 Ibid., pp. 269-272.

51 Abdul Aziz, Politik Fundamentalis: Majelis Mujahidin Indonesia dan Cita-cita Penegakan Syariat Islam (Yogyakarta: Institute of International Studies, 2011), pp. 85, 92, and p. 100.
} 
MMI understanding is based on normative and textual reading of the Holy Qur'an and Prophet tradition.

The goal of MMI establishment as revealed in its Yogyakarta Pledge is five folds. The first is the obligation of Muslims to observe sharia. The second is opposition to any other ideologies that are contradictory to Islamic teaching, since it will result in idolatry and hypocrisy, as well as will result in violating human rights. The third is building a strong front of mujahidin, in local, national and international levels. The fourth is to establish an imämah (khiläfah) or Islamic political leadership worldwide. The fifth is to call for the intensification of Islamic da'wa and jihad to realize Islam as rahmah li al-älamin (blessing for mankind). 52

The essence of these five mission statements is the idea of implementing sharia by the state and establishing Islamic caliphate. According to Abdul Aziz, the desire to estanlish Islamic state is the prerequisite of the implementation of sharia. MMI formulated this idea by referring to the efforts conducted by several Indonesian Muslim hardliners of Negara Islam Indonesia (NII). ${ }^{53}$ However, given the different context and resources, MMI tend to be more lenient in term of absence of military options. Considering its ultimate goal to establish Islamic state in Indonesia, many MMI sympathizers hope that MMI will become the true successor of NII. ${ }^{54}$

After describing HTI and MMI in detail, it is safe to say that both HTI and MMI have the inspiration to implement sharia and to establish Islamic caliphate to safeguard the implementation of sharia. These two organizations are campaigning for the pure Islam and exclusive in responding other understanding of Islam. This attitude arguably is originated in their scriptural and literal reading to the Holy Quran and Prophet tradition.

\section{Responses of Indonesian Muslim Fundamentalists on ISIS' Caliphate Claim}

After the demise of Saddam Hussein in Iraq, many Muslims believe that the next step is reconciliation and rehabilitation of all

\footnotetext{
52 Taufik Adnan Amal and Samsu Rizal Panggabean, Politik Syari'at Islam: Dari Indonesia Hingga Nigeria (Jakarta: Pustaka Alvabet, 2004), p. 77.

53 Aziz, Politik, p. 100.

${ }^{54}$ Jamhari and Jajang Jahroni, Gerakan Salafi Radikal di Indonesia (Jakarta: RajaGrafindo Persada, 2004), p. 48.
} 
aspect of life. However, the succeeding leadership under prime minister Nūrī al-Mālikī has failed to do this. Corruption in his administration and the conflict between the ruling Shiite and Sunnite increasingly escalate. Sunnite who are excluded from the existing political arrangement feel that they are treated unfairly. This helps the increase of ISIS popularity among Iraqi Sunnite Muslims.

Banking on that context, Sunnite Muslims are divided whether to support or oppose ISIS. Several Sunnite clerics blatantly oppose ISIS, such as Adnan al-Aroor and Abu Basir al-Tartusi even call ISIS as terrorists and do not represent Sunnism. The accuse ISIS as Khawarij and anti-Islam. ${ }^{55}$ Worldwide Muslim cleric association (IUMS) led by well-known Egyptian Yūsuf al-Qarḍāwīis also issue a fatwa (nonbinding opinion) stating that ISIS declaration of caliphate as not valid from the perspective of sharia. ${ }^{77}$

Not only moderate Muslims who oppose ISIS, the opposition to ISIS is also expressed by Muslim fundamentalist groups in Indonesia. HTI responds ISIS declaration of caliphate as not valid because it did not meet four requirements. The first is that ISIS does not have autonomous territory. The current occupied territory of ISIS is still legally belongs to Iraq and Syria. In addition, the territory is occupied by force, so that it does not belong to ISIS de jure. The second, and still related to the first, is that Iraq and Syria as the rightful owner of territory still demand the territory to be returned to them and do so by force. Thus, ISIS can not guarantee the security of Muslims living in that territory. The third is that ISIS is unable to implement sharia comprehensively (käffah). The fourth is that a caliphate should be led by a caliph who is a Muslim, adult, male, freeman, sane, capable and just. ${ }^{58}$

55 http://id.wikipedia.org/wiki/Negara_Islam_Irak_dan_Syam, accessed on 28 November 2014.

56 According to Fealy and Bubalo, al-Qardāwīi is influential Muslim scholar with far reaching audience. His ideas are broad, topical, contemporary, and easy reading. AlQarḍ̄āwìs ideas are often referred to by Muslim activists. See Fealy and Bubalo, Jejak, p. 66.

57 http://id.wikipedia.org/wiki/Negara_Islam_Irak_dan_Syam, Accessed on 28 November 2014.

58 http://hizbut-tahrir.or.id/2014/08/06/jubir-hti-pemerintah-harus-sikapi-isis-dankhilafah-secara-proporsional/, accessed on 29 November 2014. 
Ismail Yusanto, the spokesperson of HTI, stated that ISIS never showcases its concept of sharia in the aspects of politics, economy, legal, and the rest of sharia aspects. ${ }^{59}$ So, it is hard to determine the soundness of ISIS's sharia. In addition, ISIS caliphate remains hidden even though it has declared its existence in 2007. This mechanism contradicts the practice that had been laid down by the prophet Muhammad in Madinah caliphate. Moreover, HTI insists that caliphate should be achieved by peace and da'wa, not by force as ISIS has done. ${ }^{60}$ ISIS' caliphate is a distortion of the true meaning of caliphate and excludes the rest of Muslims who oppose it. Thus, HTI considers that ISIS's caliphate is illegitimate.

Similar to HTI's point of view, MMI also considers ISIS's caliphate as illegitimate. Muhammad Thalib, a leader of MMI, says that ISIS has spread lies under the name of caliphate. The appointment of alBaghdādī as caliph was not conducted in procedural way and this can trigger conflict among Muslims. In addition, ISIS considers other Muslims who oppose its caliphate as infidels. MMI is on the position that whoever calls Muslims to approve him as caliph without mushäwarah (consultation), as al-Baghdādī did, is heretic. ${ }^{61}$

The opposition of HTI and MMI toward al-Baghdādī's declaration as caliph does not necessarily means that the two groups differ significantly to ISIS. In fact, HTI, MMI and ISIS share ideological features in many respects, but differ in term of method and strategy. For a start, HTI and MMI do not use force and military campaign in their activity. Instead, they employ persuasive approach. To make things more complicated, there are sharp difference as well between MMI and HTI. MMI tends to engage in academic and political discourse. Its main priority is implementation of sharia and the emphasis of the establishment of caliphate comes second. MMI asserts that sharia will be well-implemented by the state when three features are realized. The first is that Muslim leadership of the country must be assumed by Muslims who are committed to the implementation of sharia. The second is that state policy must always correspond with

59 http://hizbut-tahrir.or.id/2014/08/12/hti-isis-tak-penuhi-kriteria-syari'at-dirikankhilafah, accessed on 29 November 2014.

60 http://www.muslimedianews.com/2014/08/tanggapan-gerakan-gerakan-islam-terhadap.html, accessed on 29 September 2014.

61 http://nasional.news.viva.co.id/news/read/529558-dua-unsur-sesat-isis-menurutmajelis-mujahidin-indonesia, accessed on 16 August 2014. 
sharia. The third is the presumed creation of Islamic civilization laid upon Islamic theology. It can be summed up that MMI's main goal is comprehensive implementation of sharia. MMI believes that implementation of sharia will likely to be achieved using bottom-up strategy with the ultimate implementation of sharia in national level at the end. ${ }^{62}$

In contrast to MMI, HTI opposition to ISIS is more political in nature. ${ }^{63}$ HTI believes that ISIS was born from internal conflict between Sunnite and Shiite in Iraq with the final objective of taking over the power from the al-Mālikì's Shiite regime. This Shiite regime had taken over the power with the help of the United States and its allies. ${ }^{64}$ The leadership and membership ISIS are those of Saddam Hussein loyalists. Thus, from HTI's perspective, ISIS is merely a political vehicle of those loyalists and abuse the term of caliphate as political commodity.

\section{Caliphate in the Perspective of HTI, MMI, and ISIS}

The main goal of ISIS' caliphate is the creation of political authority to implement sharia in all aspects of Muslims life. In this sense, all Indonesian fundamentalist groups, including HTI and MMI, approve, because this is also their main ideological goal. However, HTI and MMI disapprove ISIS simply because of ISIS' method and strategy. HTI and MMI oppose ISIS' brute violence and militaristic strategy because caliphate must be founded with peace and negotiation.

Many Indonesian Muslim intellectuals has been aware of the contemporary fundamentalist movements in Indonesia. Ali Maschan Moesa, a Muslim intellectual from Nahdlatul Ulama, for instance, asserts that Islamic fundamentalism understand the religion as universal. This in the past was known as pan-Islamism. The main

62 Aziz, Politik, p. 177 and p. 191.

${ }^{63}$ The opposition of HTI and MMI to ISIS cannot be generalized to groups affiliated to Shiite. Groups such as Hiz̧ al-Da'wah al-Islamiyah and other movements affiliated to it in the Middle East, Jihäd al-Isläm and 'Amal al-Islam in South Lebanon, including Hižb Allahb is the supporters of Shiite revolutionary movement who was mobilized by Islamic Republic of Iran founded on theological philosophy of Ayatullah Khomaini's wilàyat al-faqīh. See Shireen T. Hunter, Politik. Kebangkitan Islam Keragaman dan Kesatuan, translated by Ajat Sudrajat (Yogyakarta: Tiara Wacana, 2001), p. 18.

64 http://www.republika.co.id/berita/internasional/timur-tengah/14/08/05/n9so29benarkah-isis-ingin-mewujudkan-khilafah, accessed on 29 November 2014. 
feature of this movement is its desire to implement sharia interpreted from the sacred texts in textual-normative and scripturalistic. ${ }^{65}$ In this interpretation, sharia should be implemented comprehensively, not partially. Any contradicting values and culture is rejected under the pretext of against the sharia. In term of strategy and method, Oliver Roy divides the Muslim fundamentalists into two types, namely evolutionists and reformists (reformists). According to revolutionists, the islamization of the umma (Muslim community), must be done by firstly taking over the power. This group choose non-cooperative measure and refuses democracy which they consider not Islamic. ISIS falls into this category, since it uses force. Internally, al-Baghdādî̀s ISIS fights against the authority of Iraq and Syria whom it considers infidels. In global level, ISIS challenges the domination of the Unites States whom it considers to be held responsible for Iraq's political turmoil. 66

On the other hand, evolutionist model believes that their social and political actions are aimed at re-islamizing the umma from bottom and moving up to establish an Islamic state. ${ }^{67}$ Indonesian fundamentalist groups of HTI and MMI are included into this category. They do not have the plot to topple down the power and do not consider the existing political arrangements are infidel, although they also wish that the global US domination must end. They campaign for the implementation of sharia and the establishment of caliphate in transformative manner. Thus, the opposition of HTI and MMI to ISIS' caliphate is a question of the means and method of how to get the power and how to implement sharia. It is the question whether violence, political opposition, collaboration or political disengagement should be deployed as strategy. The fact shows that when ISIS proclaimed the caliphate for a second time on June $29^{\text {th }}$, 2014, HTI and MMI opposed it and certainly disagreed with the ISIS'

65 Ali Maschan Moesa, Nasionalisme Kiai: Konstruksi Sosial Berbasis Agama (Yogyakarta: LKiS, 2007), pp. 278-295.

${ }^{66}$ Sunnite fundamentalist groups who choose to revolutionary model are represented by Tanżim al-Qä'idah led by Usama bin Laden and its network, Abū Mus'ab al-Zarqāwī 's group in Iraq, al-Jama'a ab Islamiyah in Southeast Asia and Juma Namangani movement in ex-soviet countries in Central Asia. See Rahmat, Arus, p. 18.

67 Oliver Roy, Gagalnya Politik Islam, translated by Harimurti and Qomaruddin SF (Jakarta: Serambi, 1996), p. 29. 
violence. ${ }^{68}$ This means they are evolutionists (reformists), clearly in the opposite of ISIS.

ISIS revolutionary movement aims at establishing caliphate and forcefully implementing sharia. This model of caliphate is different from the model that HTI and MMI use. Even though ISIS has successfully established a de facto caliphate along with caliph, territory, umma (citizens), governance arrangement, armed forces, public administration, and income resources, HTI and MMI opposed ISIS caliphate.

The reason of HTI should also be understood by observing the fact that caliphate of ISIS does not fit the criteria that HTI has outlined. The trend and interest of HTI politics should be fully comprehend. The opposition of HTI to ISIS caliphate does not concern the principles, which they both share, but it relates to detail issues or the adoption of different strategies. MMI also oppose ISIS of this unsubstantial ground. They consider ISIS as heretical simply because ISIS applied violence means in realizing its caliphate.

Regardless the difference in methods and means, contemporary Muslim fundamentalists have the aspiration to establish caliphate. This aspiration is originally inspired by the reform of Afghānī, 'Abduh, Rị̣ā, and Sayyid Quṭb in the Nineteenth Century CE. Afghānī was known as salafi leader who direcly involved in international movement against West colonialism and imperialesim in Muslim world. ${ }^{69} \mathrm{He}$ was known as reformist rather that political and cultural activist. Afghānī uses religious injunctions for reform and believes that the glory of Islam can be revived by returning to the basic teaching of Islam that was applied by early Muslims (al-salaf al-sälih). ${ }^{70}$.

The mission of Afghānī later was carried out by 'Abduh"1 and Rị̣ā. Rị̣ā believes that Islam is a comprehensive religion and provides all necessary teachings for Muslims, including political, economy and

\footnotetext{
68 Aula, Telah Labir, p. 45.

${ }^{69}$ Sadzali, Islam, pp. 116-117.

${ }^{70}$ The idea of salafìyah was not originally from Afghānī because there was IbnTaymīyah and Muḥammad 'Abd al-Waḥhāb who respectively in XII and XVIII CE spoke the similar ideas. See Sadzali, Islam, pp. 124-125.

71 After graduated from al-Azhar University, Abduh taught in Dār al-Ulüm school in Egypt. Then he met Afghānī and formed a solidarity organization called al-Urwah alWuthqā (1884). See Abdel-Malek (ed), Contemporary, p. 39.
} 
social systems. To reclaim the glorious past, Muslims must not imitate the West. Riḍā's conviction influence Hasan al-Bannā' dearly, whose al-Ikhwān al-Muslimūn had very negative tone for the West. ${ }^{72}$

Similar to Hasan al-Bannā, Sayyid Quṭb as his successor was a sheer thinker. He outlines three thoughts that became the concept of caliphate for contemporary fundamentalist movements. The first is the creation a Pan-Islam and centralistic government across the current political boundary. The second is equal rights for all citizens regardless different religious backgrounds in which Islam guarantee the protection and safety for non-Muslims living within its boundary to observe religion. It also will guarantee equality among citizens and aims at realizing humanism and freedom of religion. The last is justice, people obedience and consultation. ${ }^{73}$

The aforementioned thoughts of salafi thinkers become the ideology of Sunnite fundamentalist movements, notably al-Ikhwān alMuslimūn, regardless revolutionary or transformative. They bring salafi mission of the comprehensiveness of Islamic teaching, application of sharia, purification, and caliphate. After them, there were 'Abd al-A'lā al-Mawdūdī, Taqiy al-Dīn al-Nabhānī, Yūsuf al-Qarḍ̄āī, and other salafi thinkers. Special account must be attributed to Afghānī who first set the principles of movement and adopted revolutionary approach. After him, there are in contrast, 'Abduh and Riḍā were keen to use reform and transformation. In this context, ISIS is more likely to adopt Afghānī, whereas HTI and MMI are closer to, mainly, Rị̣ā who inclined to use transformative approach.

Broadly speaking, Muslim fundamentalist movements that have transformative approach in Indonesia tend to align their agenda with the existing context by accepting Indonesia's political arrangement albeit reluctantly. Yet, some small groups categorically do not accept the state ideology and create tension here and there. They accept democracy as a means to achieve their ultimate goal. Whereas ISIS, it refuses all modern system, including democracy, constitution and nation state. ISIS put Islam as state ideology and official state religion. It launches jihad campaign to take over the power by all forms of

\footnotetext{
${ }^{72}$ Lihat Sadzali, Islam, pp. 145, 147. Read Abdel-Malek (ed.), Contemporary, p. 45.

${ }^{73}$ Ibid.
} 
force, including open warfare. It is clearly revolutionary to the extreme. ${ }^{74}$

Admittedly, ISIS in one side and HTI and MMI on the other side have identical underlying principles and goals, notably the establishment of caliphate. The difference lies only in their strategies in facing social and political situation. While Indonesian fundamentalist groups of HTI and MMI adopt the transformative approach with structural transition process, ISIS is revolutionary with the immediate intention of taking over the power. While HTI and MMI use gradual campaign and realistic in assessing the condition before jumping into establishing caliphate, ISIS tends to seize the moment to establish its version of ideal caliphate albeit on unfertile ground.

\section{Conclusion}

The campaign of al-Baghdādī principally is identical to those other fundamentalist groups in general. They all are on the conviction that when caliphate is established, sharia will be comprehensively applicable. They all are on the opinion that caliphate has conclusive normative textual foundation. As a result, the establishment of caliphate is a necessity. In bold and violent measure, and seizing the turmoil momentum in the region, al-Baghdādī established ISIS, Islamic State of Iraq and Syria.

Indonesian Muslim fundamentalist groups such as HTI and MMI opposed ISIS' caliphate claim. This opposition does not concern with the main concept, principles and objective of an Islamic caliphate. Instead, their opposition lies upon different type of modes of realizing their goal. While al-Baghdādī establishes ISIS using revolution and force, Indonesian fundamentalist groups adopt peaceful and transformative da'wa (evolution).

Normatively speaking, the obligation to establish caliphate is unfounded in Islam. Instead, caliphate was deployed as a political institution, but never in vacuum. Thus, caliphate was subject of change and modification. Caliphate emerged from Muslim social improvisation that evolved in time and space. Therefore, modern political arrangements that have similar feature to caliphate should be

\footnotetext{
${ }^{74}$ In contemporary Shiite context, the Islamic Republic of Iran with the ideology of Islam wilayat al-faqīh can be categorized revolutionary fundamentalist. It applied literalistic Islamic law that includes stoning for adulterers. Haideh Moghissi, Feminisme dan Fundamentalisme Islam, translated by M. Maufur (Yogyakarta: LKiS, 2004), p. 133.
} 
considered valid. Publicly elected leadership is acceptable as the rightful authority because public consensus is legally binding in Islam.]

\section{References}

\section{Books and Articles}

Afdlal et.al. Islam dan Radikalisme di Indonesia. Jakarta: LIPI Press, 2005.

A'la, Abd. Jahiliyah Kontemporer dan Hegemoni Nalar Kekerasan: Merajut Islam Indonesia Membangun Peradaban Dunia.Yogyakarta: LKiS, 2014.

Ali, As'ad Said. Al-Qaeda: Tinjanan Sosial-Politik, Ideologi dan Sepak Terjangnya. Jakarta: LP3ES, 2014.

Amin, Ainur Rofiq (al). Membongkar Proyek Kbilafah Ala Hiz̧but Tabrir di Indonesia.Yogyakarta: LKiS, 2012.

Aziz, Abdul. Politik Fundamentalis: Majelis Mujahidin Indonesia dan Cita-cita Penegakan Syariat Islam.Yogyakarta: Institute of International Studies, 2011.

Aula. "Telah Lahir Negara Khilafah," in Majalab Nabdlatul Ulama. ed. XXXVI, August 2014,

Azra, Azyumardi. Pergerakan Politik Islam: Dari Fundamentalisme, Modernisme Hingga Post-Modernisme. Jakarta: Paramadina, 1996.

Choir, Tholhatul and Fanani, Ahwan (ed.). Islam dalam Berbagai Pembacaan Kontemporer. Yogyakarta: Pustaka Pelajar, 2009.

Djazuli, A. Figh Siyasab: Implementasi Kemaslahatan Umat dalam Ramburambu Syari'ah. Jakarta: Kencana, 2003.

Fealy, Greg and Bubalo, Anthony. Jejak Kafilab: Pengarub Radikalisme Timur Tengah di Indonesia. Translated by Akh. Muzakki. Bandung: Mizan, 2007.

Hamim, Thoha. Islam dan NU di Bawah Tekanan Problematika Kontemporer: Dialektika Kehidupan Politik, Agama, Pendidikan dan Sosial Masyarakat Muslim. Surabaya: Diantama, 2004.

Hunter, Shireen T. Politik Kebangkitan Islam Keragaman dan Kesatuan. Translated by Ajat Sudrajat.Yogyakarta: Tiara Wacana, 2001. 
Jindan, Khalid Ibrahim. Teori Politik Islam: Telaah Kritis Ibnu Taimiyah Tentang Pemerintahan Islam. Surabaya: Risalah Gusti, 1999.

Kompas. "Dilarang Penyebaran Paham ISIS". 5 August 2014.

Lewis, Bernard. Political Language of Islam. Chicago: University of Chicago Press, 1988.

------. The Crisis of Islam (Islam dalam Krisis: Antara Perang Suci dan Teror Kotor).Translated by Muhammad Harir Muzakki. Surabaya: Jawa Pos Press, 2004.

Machmudi, Yon. Partai Keadilan Sejabtera: Wajah Baru Politik Islam Indonesia. Bandung: Harakatuna Publishing, 2005.

Mahendra, Yusril Ihza. Modernisme dan Fundamentalisme dalam Politik Islam: Perbandingan Partai Masyumi (Indonesia) dan Partai Jama'at-iIslami (Pakistan). Jakarta: Paramadina, 1999.

Malek, Anouar Abdel (ed.). Contemporary Arab Political Thought. Bath: The Pitman Press, 1980.

Maulani, Z.A. et.al. Islam dan Terorisme: Dari Minyak Hingga Hegemoni Amerika. Yogyakarta: Ucy Press, 2005.

Moghissi, Haideh. Feminisme dan Fundamentalisme Islam. Translated by M. Maufur. Yogyakarta: LKiS, 2004.

Moesa, Ali Maschan. Nasionalisme Kiai: Konstruksi Sosial Berbasis Agama.Yogyakarta: LKiS, 2007.

Mubaraq, Zulfi. Tafsir Jihad: Menyingkap Tabir Fenomena Terorisme Global. Malang: UIN-Maliki Press, 2011.

Muhammad, Reno. ISIS: Kebiadaban Konspirasi Global. Jakarta: Noura Books, 2014.

Mūsā, Muḥammad Yūsuf. Niżām al-Hukem fì al-Islām. al-Qāhirah: Dār al-Kitāb al-'Arabī, 1963.

Nabhānī, Taqiy al-Dīn (al). al-Dawlah al-Islamìyah. Beirut: Dar al‘Āmmah, 1994.

Rahmat, M. Imdadun. Arus Baru Islam Radikal: Transmisi Revivalisme Islam Timur Tengab ke Indonesia. Jakarta: Erlangga, 2007.

Rais, Dhiauddin. Teori Politik Islam. Translated by Abdul Hayyie alKattani. Jakarta: Gema Insani Press, 2001. 
Ridwan, Nur Khaliq. Regenerasi NII: Membedab Jaringan Islam Jihadi di Indonesia. Jakarta: Erlangga, 2008.

Roy, Olivier. Gagalnya Politik Islam. Translated by Harimurti dan Qomaruddin SF. Jakarta: Serambi, 1996.

Sjadzali, Munawir. Islam dan Tata Negara: Ajaran, Sejarah dan Pemikiran. Jakarta: UI-Press, 1993.

Takwin, Bagus. Akar-Akar Ideologi: Pengantar Kajian Konsep Ideologi dari Plato Hingga Bourdieu.Yogyakarta: Jalasutra, 2008.

Taymīyah, Ibn. Minhāj al-Sunnah. Beirut: Dār al-Kutub, t.t.

Watt, William Montgomery. Fundamentalisme Islam dan Modernitas. Translated by Taufik Adnan Amal. Jakarta: RajaGrafindo, 2001.

Zallūm, 'Abd al-Qadīm. Niẓām al-Hukem fì al-Islām. Beirut: Dār al'Āmmah, 1992.

Zaydan, 'Abd al-Qādir. al-Fard wa al-Dawlah fì al-Shari'ah al-Islāmìyah. alIjtihād al-Islāmī al-‘Alamī, 1970.

\section{Internet Sources}

http://heniputra.my.id/isis-jatuh-ke-dalam-perangkap-deklarasikhilafah-yang-tidak-akan-merubahnya-dari-sebuah-kelompok. Accessed on 28 of November 2014.

http:/ / hizbut-tahrir.or.id/2014/08/06/jubir-hti-pemerintah-harussikapi-isis-dan-khilafah-secara-proporsional/. Accessed on 29 of November 2014.

http:/ / hizbut-tahrir.or.id/2014/08/12/hti-isis-tak-penuhi-kriteriasyari'at-dirikan-khilafah. Accessed on 29 of November 2014.

http://id.wikipedia.org/wiki/Negara_Islam_Irak_dan_Syam. Accessed on 28 of November 2014.

http:/ / nasional.news.viva.co.id/ news / read/529558-dua-unsur-sesatisis-menurut-majelis-mujahidin-indonesia. Accessed on 16 of August 2014.

http:/ / nasional.news.viva.co.id/ news / read/529558-dua-unsur-sesatisis-menurut-majelis-mujahidin-indonesia. Accessed on 18 of November 2014.

http://www.eramuslim.com/suara-kita/suara-pembaca/menggempurisis.htm\#.VGk43FfXvIU. Accessed on 28 of November 2014. 
http://www.muslimedianews.com/2014/08/tanggapan-gerakangerakan-islam-terhadap.html. Accessed on 29 of September 2014.

http://www.muslimedianews.com/2014/08/tanggapan-gerakangerakan-islam-terhadap.html. Accessed on 18 of November 2014.

http://www.republika.co.id/berita/internasional/timurtengah/14/08/05/n9so29-benarkah-isis-ingin-mewujudkankhilafah. Accessed on 29 of November 2014.

http://www.tempo.co/read/news/2014/07/01/118589519/MisiBerbelok-ISIS-Tak-Akur-dengan-Al-Qaidah. Accessed on 29 of November 2014. 